\title{
Rewitalizacja opuszczonych ośrodków wypoczynkowych z okresu Polski Ludowej jako forma wsparcia lokalnej turystyki na Mazurach
} Revitalization of abandoned holiday resorts from the People's Republic of Poland as a form of support for local tourism in Masuria

\begin{abstract}
Streszczenie
W artykule przedstawiono charakterystykę obiektów turystycznych obszaru Mazur z okresu Polski Ludowej oraz przeanalizowano możliwości rewitalizacji ośrodków opuszczonych w celu pobudzenia lokalnej gospodarki. Przeprowadzono analizy poszczególnych typów obiektów turystycznych z lat 1945-1989 na podstawie wizji lokalnej oraz krytycznej analizy literatury. Opracowanie zawiera opis obecnego stanu prezentowanych przykładów. Każdy z nich został wybrany jako przedstawiciel jednego typu zabudowy ośrodków turystycznych, charakterystycznego dla przyjętych ram czasowych.
\end{abstract}

Słowa kluczowe: Mazury, turystyka, Polska Ludowa, ośrodek wypoczynkowy

Abstract

This article presents the characteristics of tourist facilities in Masuria from the period of the People's Republic of Poland and focuses on the possibility of revitalizing abandoned centers in order to stimulate the local economy. Analyzes of individual types of tourist facilities from 1945-1989 were carried out on the basis of a local vision and a critical analysis of the literature. The study describes the current state of the presented examples. Each of them was selected as a representative of one type of development of tourist centers, characteristic for a given period.

Keywords: Masuria, tourism, People's Poland, holiday center 


\section{WSTĘP}

Mazury cechuje unikatowy krajobraz i charakterystyczna tkanka geologiczna, stanowiąca interaktywną opowieść o dziejach ziemi oraz otaczającej naturze. Dla Polaków południowe rejony pojezierza stanowią lekcję historii nie tylko kształtowania się krajobrazu, ale przede wszystkim historii kraju. Szczególnie istotną rolę w regionie odgrywa tzw. turystyka pokoleń, na którą mają wpływ przemiany kulturowe i cywilizacyjne, zamożność społeczeństwa i forma zatrudnienia (Wasyluk i in., 2018). Zauważalne są tu związane z tym wzrosty i spadki w sektorze turystyki na przestrzeni lat. Rok 1945 to początek kształtowania się turystyki na tym obszarze i tworzenia pierwszych ośrodków wypoczynkowych na masową skalę. Lata 1945-1989, czyli okres Polski Ludowej, to czas intensywnej ekspansji turystycznej, charakteryzujący się specyficzną strukturą kształtowania zarówno turystyki, jak i formy architektonicznej obiektów wypoczynkowych. Obecnie turystyka na terenie Mazur jest jednym z najbardziej zaniedbanych sektorów usług. Brak stałego rozwoju, a jednocześnie starzenie się infrastruktury sprawiły, że liczba opuszczonych ośrodków zaczęła systematycznie rosnąć. Jednocześnie widać brak pomysłów na poradzenie sobie z zaistniałym problemem. Jest to niewykorzystany potencjał regionu, który daje szansę na poprawę jakości życia mieszkańców całego województwa.

\section{CEL, ZAKRES, METODYKA}

Celem badań jest weryfikacja obecnego stanu dawnych ośrodków turystycznych na terenie Mazur oraz przygotowanie wytycznych związanych z ich rewitalizacją. Przywrócenie jakości opuszczonym obiektom powinno pobudzić lokalną gospodarkę i przyciągnąć nowe pokolenia turystów na teren pojezierza. Zakres badania obejmuje ośrodki wypoczynkowe z czasów Polski Ludowej ulokowane na terenie Mazur, ze szczególnym uwzględnieniem dawnych obszarów ekspansji turystycznych. Zaproponowano klasyfikację i omówienie konkretnych typów zabudowy, takich jak: rozproszona zabudowa domków letniskowych, niska zabudowa szeregowa, wielofunkcyjne budynki z wielkiej płyty. Na podstawie wizji lokalnej, której efektem była analiza wrażeniowa, a także krytycznej analizy literatury sporządzono studium poszczególnych przykładów dawnej zabudowy ośrodków turystycznych. Oceniając całokształt architektury wypoczynkowej, wskazano jej podstawowe wady i zalety, które następnie przełożono na współczesne realia i potrzeby konsumentów. 


\section{TURYSTYKA NA TERENIE MAZUR}

Województwo warmińsko-mazurskie jest podzielone na 19 powiatów i dwa miasta na prawach powiatu. Istnieje również podział województwa na krainy, który ma charakter bardziej kulturowo-historyczny i dzieli je kolejno na: Warmię, Mazury, Barcję, Powiśle i ziemię lubawską (Naruszewicz-Duchlińska, 2004). Dla architektury ważniejszy od klasyfikacji administracyjnej jest jednakże podział oparty na klasyfikacji kulturowo-historycznej. Różnice w zabudowie historycznej w poszczególnych regionach są wynikiem burzliwej historii, zamieszkiwania przez konkretną grupę etniczną, a także obranej przez nią religii (Achremczyk, 2010-2011). Zarówno nowo powstałe obiekty turystyczne, jak i te pochodzące z drugiej połowy XX wieku nie mają charakterystycznych regionalnych elementów architektonicznych. Brak unikatowego programu turystycznego, który wyzwoliłby miejscowy potencjał, zauważył zarząd województwa warmińsko-mazurskiego, czego efektem jest powstanie Strategii Rozwoju Turystyki Województwa Warmińsko-Mazurskiego do roku 2025. Według opracowanej strategii turystyka ma się stać wiodącą dziedziną gospodarki, wywierającą pozytywny wpływ na wszystkie jej sektory (Urząd Marszałkowski Województwa Warmińsko-Mazurskiego, 2016b) ${ }^{1}$. Ze zgromadzonych danych wynika, że województwo warmińsko-mazurskie jest jednym z trzech najchętniej odwiedzanych województw na terenie Polski. Większość stanowią turyści krajowi (88,1\%), pozostali to turyści zagraniczni - dane na rok 2020 (Urząd Marszałkowski Województwa Warmińsko-Mazurskiego, 2016a). Analizując obecny stan dawnych ośrodków turystycznych, warto zwrócić uwagę także na zapotrzebowanie na konkretną funkcję i rodzaj turystyki. W ciągu ostatniej dekady znacznie wzrosła liczba hoteli i pensjonatów na terenie całego województwa. W tym samym czasie bardzo skurczyła się liczba ośrodków wypoczynkowych, kolonijnych i uzdrowiskowych (Urząd Statystyczny, 2020). Przy czym to właśnie te obiekty charakteryzował najdłuższy czas pobytu turystów. Obecnym celem regionu jest turystyka rekreacyjna i sportowa, która stanowi około 47\% całej oferty turystycznej (Urząd Marszałkowski Województwa Warmińsko-Mazurskiego, 2016a).

Turystyka na Mazurach zaczyna się od najmniejszej jednostki, jaką jest wynajem domu jednorodzinnego, a kończy na szerokim wachlarzu ofert hotelarskich. Badania biorą pod uwagę turystykę zbiorową, budowaną na przestrzeni drugiej połowy XX wieku, którą obecnie stanowią pustostany, niemożliwe do likwidacji.

\section{TURYSTYKA NA MAZURACH W OKRESIE POLSKI LUDOWEJ (1945-1989)}

Po drugiej wojnie światowej granice Polski powiększyły się o tzw. Ziemie Odzyskane. Mazury dopiero wtedy faktycznie stały się częścią kraju (Sakson, 1990: 54-58). Były wówczas chętnie wybieraną lokacją, wcześniej nieznaną Polakom. Zgodnie z ówczesną doktryną

1 Cel główny. 
polityczną rozwój turystyki miał mieć charakter socjalny i masowy. Według tych założeń to, co uprzednio było domeną elity, czyli podróżowanie i wypoczynek, miało stać się dobrem powszechnym. Główny nacisk kładziono na turystykę edukacyjną i socjalną, czyli przede wszystkim ośrodki kolonijne dla dzieci i młodzieży. Potrzebom takiej formy turystyki miały odpowiadać niewielkie domki letniskowe ulokowane w skupiskach, budowane z drewna lub betonu. Były to modularne, jednakowe budynki, które spełniały funkcję głównie noclegową. Pomieszczenia, które miały obsługiwać wszystkich na równym poziomie świadczenia usług, znajdowały się w osobnych budynkach specjalnego przeznaczenia, takich jak: stołówka, kuchnia, recepcja, bawialnia. Ogromną rolę w dynamicznym rozwoju turystyki odegrały wówczas związki zawodowe. Już w 1945 roku powołano Wydział Wczasów Pracowniczych, a cztery lata później Fundusz Wczasów Pracowniczych, którego głównym zadaniem było tworzenie domów wypoczynkowych, należących do konkretnych związków zawodowych lub spółek państwowych (Gryszel, 2021). FWP został powołany przez sejm na wniosek Komisji Centralnej Związków Zawodowych. Jego głównym organem decyzyjnym była rada funduszu, a wykonawczym dyrekcja naczelna, której bezpośrednio były podporządkowane ośrodki wypoczynkowe. Każdy, kto chciał się udać na wypoczynek, był zmuszony nie tylko do złożenia rezerwacji i uiszczenia kwoty, ale także do otrzymania skierowania. Skierowanie było podyktowane renomą placówki pracowniczej w szeregach politycznych oraz niejednokrotnie odpowiednimi znajomościami w gronie osób decyzyjnych. FWP sprawował wówczas monopol w sektorze turystyki na terenie całego kraju i to za jego sprawą budowano kolejne placówki wczasowe.

Wraz z powstawaniem coraz większej liczby domów i ośrodków wypoczynkowych można zauważyć stopniowe poszerzanie funkcji obiektów. Wiązało się to ze zwiększeniem kubatury masowo budowanych ośrodków. Powszechnym stylem była ludowa interpretacja modernizmu. Szybko zaczęły powstawać obiekty budowane z betonu, z płaskim dachem, o prostej kubaturze. Często były to formy budynków szeregowych, a z czasem ogromnych obiektów z wielkiej płyty, opartych na charakterystycznych pylonach. Rok 1989 wyznaczył symboliczny kres stawiania tego rodzaju ośrodków.

Współcześnie ze względu na wybory konsumentów i obecny stan rozwoju gospodarczego obiekty turystyczne budowane w latach 1945-1989 nie spełniają wymagań i nie zaspokajają potrzeb młodych pokoleń. Według zgromadzonych danych obiekty turystyczne o charakterze ośrodków wypoczynkowych i kolonijnych stopniowo zmniejszają swoją ofertę (Urząd Statystyczny, 2020). Ich technologia budowlana nie pozwala na likwidację lub rozbiórkę, co skutkuje coraz większą liczbą opuszczonych ośrodków, które zgodnie z filozofią zrównoważonego rozwoju powinny zostać zrewitalizowane i dostosowane do obecnych potrzeb. 


\section{ANALIZA POSZCZEGÓLNYCH PRZYKŁADÓW OŚRODKÓW WYPOCZYNKOWYCH Z OKRESU 1945-1989}

\subsection{KRYTERIA DOBORU PRZYKŁADÓW I ANALIZY}

Do analizy wybrano obiekty pełniące funkcję ośrodków wypoczynkowych, budowane w latach 1945-1989. Zakres opracowania obejmuje region Mazur, ze szczególnym uwzględnieniem ich południowego obszaru, który niegdyś stanowił główny kierunek turystyki. Wzięto pod uwagę obiekty opuszczone lub znajdujące się w bardzo złej kondycji i upadające.

Analizy, których efekty przedstawiono poniżej, oparto na opisie charakterystycznych cech architektonicznych obiektów, materiałów użytych do ich konstrukcji i wykończenia oraz rozkładu funkcji i programu, jaki zakładał ośrodek wypoczynkowy. Uzupełnieniem wniosków zaprezentowanych $w$ formie opisowej są analizy SWOT, stanowiące podstawę do opracowania wytycznych do rewitalizacji obiektów.

\subsection{CASE STUDY}

\subsubsection{ROZPROSZONE SKUPISKA DOMKÓW LETNISKOWCYH}

W grupie tej wzięto pod uwagę następujące obiekty: ośrodek wypoczynkowy „Kalwa” i kemping PTTK w Pasymiu, ośrodek wypoczynkowy WSPol w Starych Kiejkutach, ośrodek wypoczynkowy Polfa Tarchomin w Piszu, domki letniskowe „Kołbuk” w Nowej Kaletce oraz ośrodek wypoczynkowy „Bielanka” w Rucianem-Nidzie.

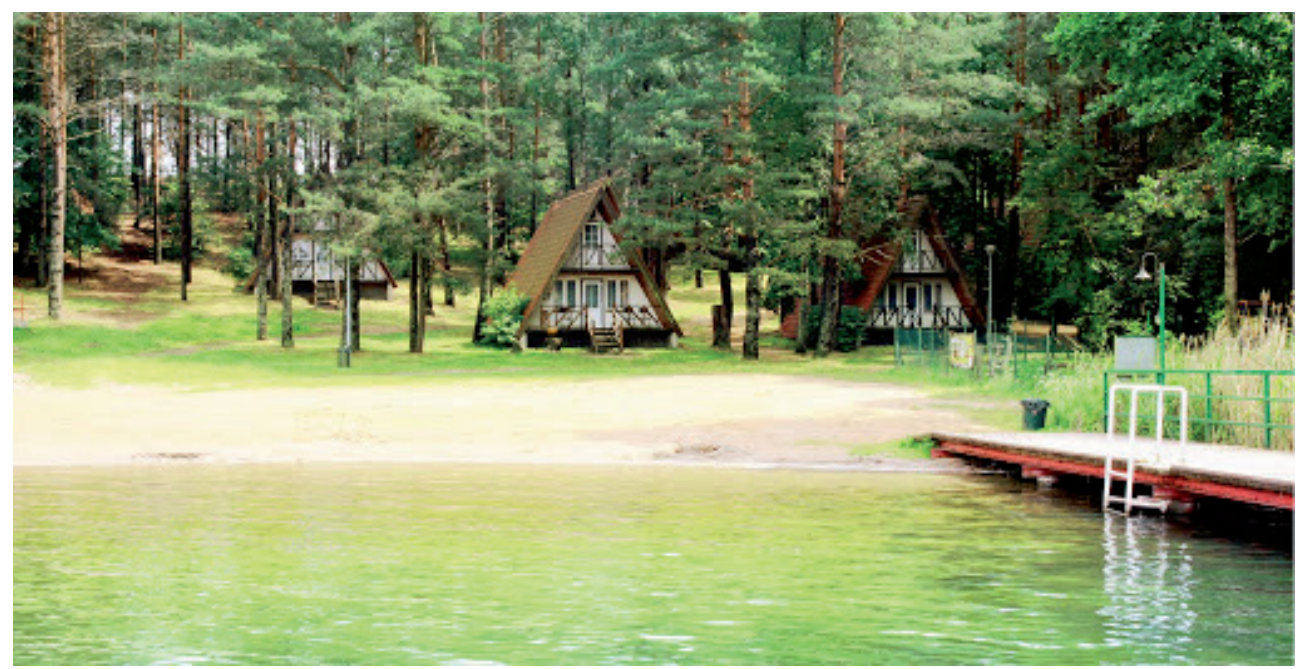

II. 1. Ośrodek wypoczynkowy „Kalwa”, Pasym (http://www.kalwa-energopol.pl/) 


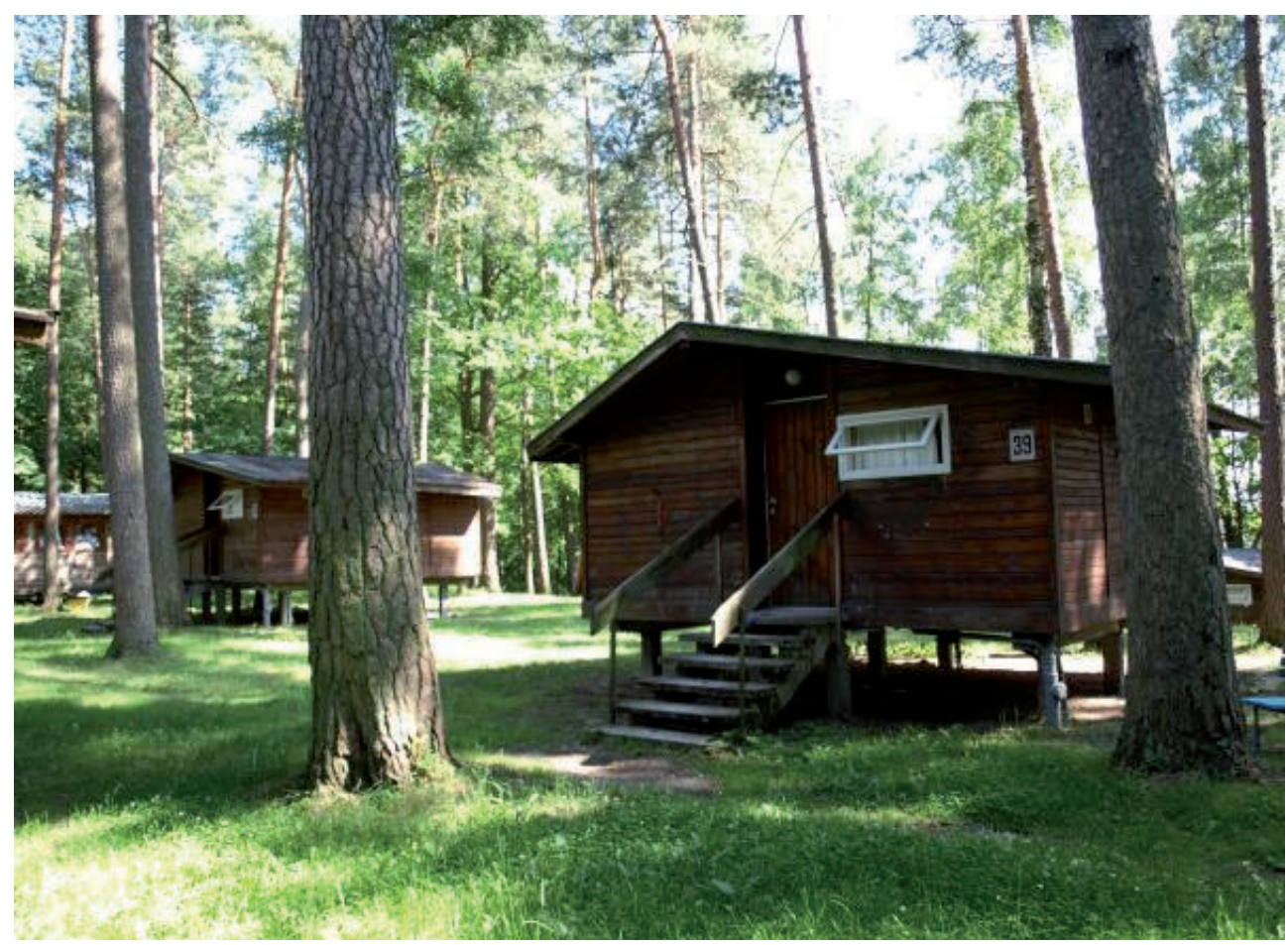

II. 2. Ośrodek wypoczynkowy „Bielanka”, Ruciane-Nida (https://www.zaplanujwczasy.pl/ noclegi+ruciane-nida/bielanka,41562.html)

\section{Charakterystyczne cechy architektoniczne}

Wolnostojące obiekty parterowe, niepołączone zagospodarowaniem terenu. Mała ingerencja w naturalny krajobraz. Zazwyczaj niewielkie budynki z drewna ze skośnymi dachami dwuspadowymi. Niektóre wersje posiadają dwie skośne połacie dachowe prowadzone do samego parteru budynku. Częstym zabiegiem jest podniesienie zabudowy ponad teren w celu uniknięcia podtopienia. Niewielkie drzwi i okna, wnętrza zazwyczaj jednoizbowe. Domki letniskowe przeznaczone do turystyki biwakowej. Zadaniem domków było zapewnienie najbardziej podstawowych potrzeb turysty, dzięki czemu większość czynności wykonywano na zewnątrz.

\section{Materiał budowlany}

Budynki przeważnie wykonane z konstrukcji drewnianej lub murowanej pokrytej deskami drewnianymi. Elewacja pozostawiona w naturalnych odcieniach lub pomalowana na kolor błękitny, bordowy itp. Dach zazwyczaj wykończony blachą. Charakterystyczne jest tu wykorzystanie tanich materiałów wykończeniowych. Duża integracja materiałów z otaczającym krajobrazem. Stolarka okienna i drzwiowa drewniana, sporadycznie malowana w stylu przypominającym archetyp zabudowy wiejskiej. 


\section{Funkcja i program}

Funkcją domków jest jedynie nocleg. Toaleta często znajduje się na zewnątrz, w innym budynku lub w ogóle jej brakuje. Kuchnia niewielka, polowa. Założenie wykorzystujące biwakowy styl turystyki, w którym często traktuje się jezioro jako miejsce kąpieli, a ognisko jako miejsce do przyrządzania posiłków. Brak zagospodarowania terenu. Obiekty nie pełnią funkcji integrującej uczestników. Często brak parkingu, a także przystosowania do wymagań przeciwpożarowych obiektów noclegowych.

\section{Analiza SWOT}

\section{MOCNE STRONY}

- Duży kontakt z naturą

- Oferta zapomnianej formy turystyki

- Ekologiczna konstrukcja i materiały wykończeniowe

- Usytuowanie w lesie lub nad brzegiem jeziora

\section{SZANSE}

- Przywrócenie dawnej formy turystyki

- Promowanie ekologicznego typu turystyki

- Rewitalizacja budynków z odwołaniem do lokalnego wiejskiego archetypu

\subsubsection{NISKA ZABUDOWA SZEREGOWA}

W tej grupie wymienić należy: ośrodek wypoczynkowy „Relaks” w Świerkocinie, ośrodek wypoczynkowy „Leśna Polana” w Mikołajkach oraz ośrodek wypoczynkowy „Mazury” w Krzyżach.

\section{Charakterystyczne cechy architektoniczne}

Obiekty parterowe, rozczłonkowana zabudowa szeregowa. Niewielka integracja z terenem, wykorzystywanie takich elementów architektury jak schody i rampy. Płaskie dachy z wysoką attyką. Brak zagospodarowania terenu. Niewielkie okna w budynkach noclegowych oraz duże przeszklenia horyzontalne w budynkach socjalnych. Wolny plan obiektów socjalnych. 


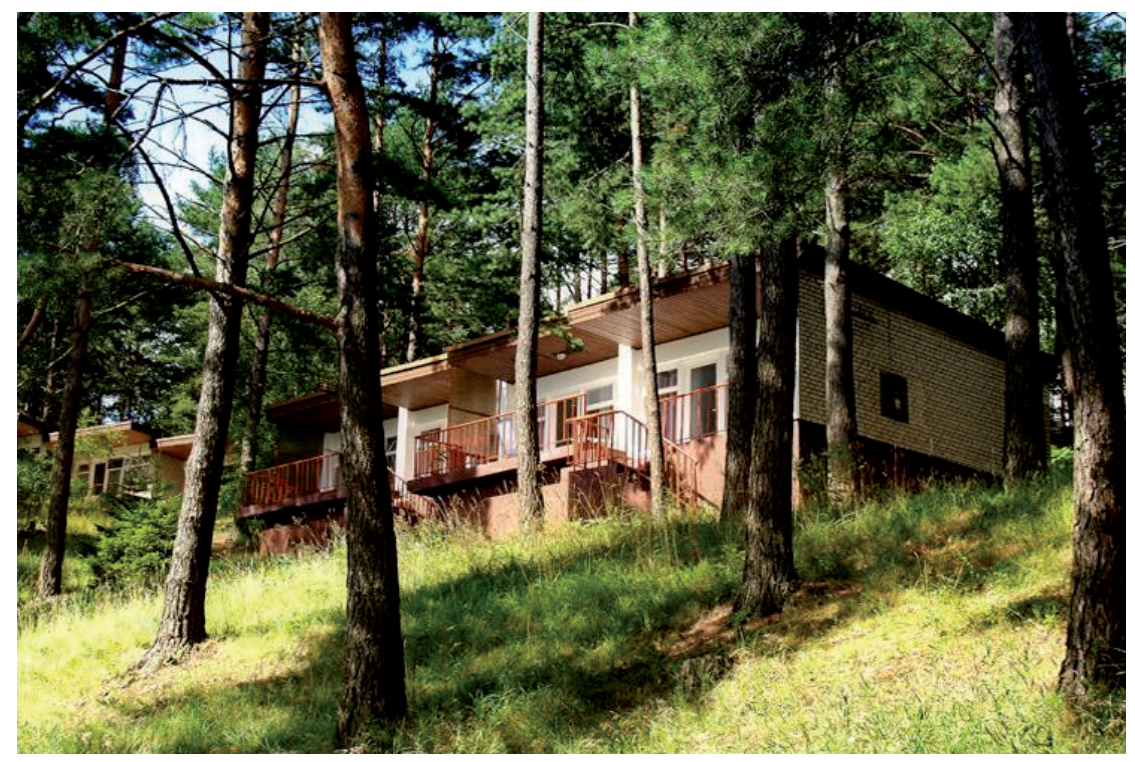

II. 3. Ośrodek wypoczynkowy „Relaks”, Świerkocin (https://zapytajonocleg.pl/obiekt-27245-olsztynekrelaks-osrodek-wypoczynkowy-swierkocin)

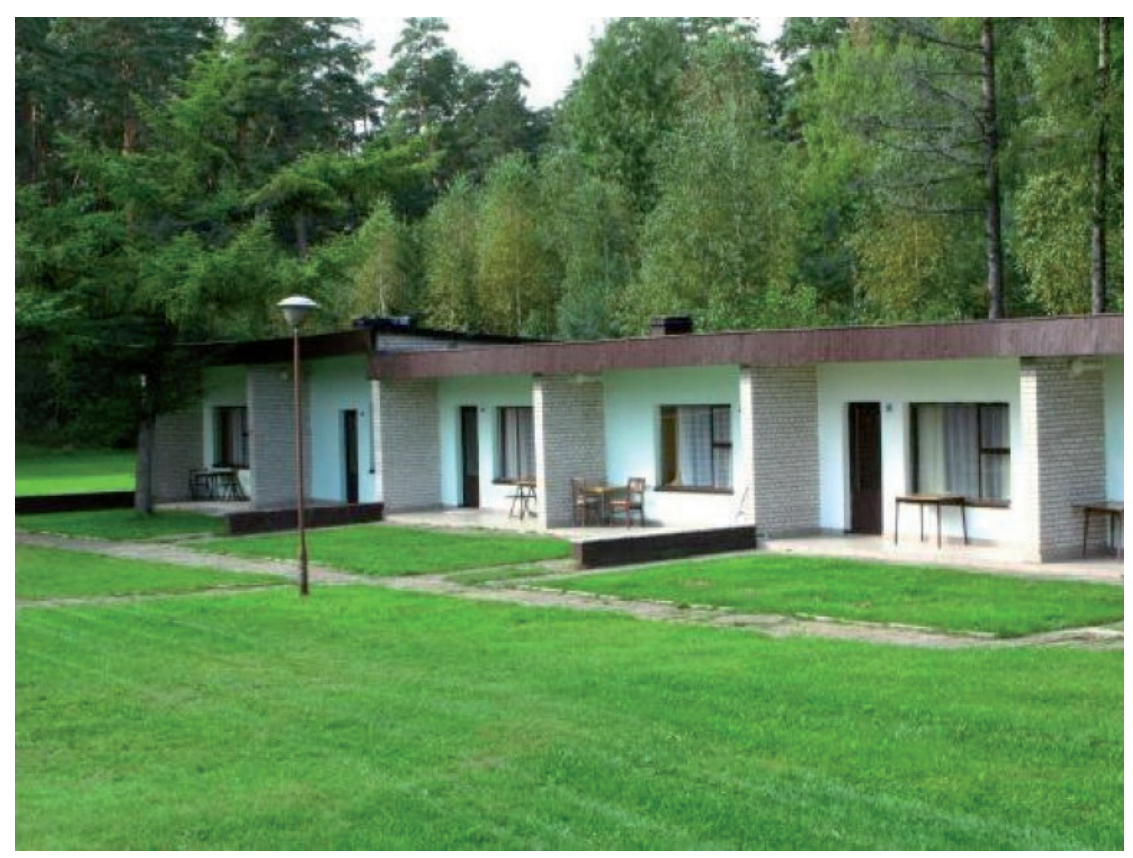

II. 4. Ośrodek wypoczynkowy „Mazury”, Krzyże (https://e-turysta.pl/osrodek-wypoczynkowy-mazurykrzyze-100661.html?kl=1) 


\section{Materiał budowlany}

Przewaga betonu zarówno w elewacji budynku, jak i w zagospodarowaniu terenu. Sporadycznie występujące elementy drewniane, głównie w postaci stolarki okiennej i drzwiowej, a także w wykończeniu wnętrz. Duże przeszklenia i elementy poręczy oraz barierek wykonane ze stali.

\section{Funkcja i program}

Wyraźny podział na poszczególne funkcje. Niewielkie kaskadowo ułożone bryły sześcienne stanowią pokój sypialniany z własnym wejściem i kawałkiem tarasu. Reszta funkcji budynku jest socjalna i dostępna dla każdego. Większe obiekty pełniące wyspecjalizowane funkcje to: recepcja, sala konferencyjna, stołówka, kuchnia, kawiarnia, sala gier oraz wspólna łazienka. Podział funkcji miał zapewniać prywatność jedynie w aspekcie noclegowym, wszystkie pozostałe funkcje obiektu miały integrować i zapewniać równość otrzymywanych usług. Poszczególne elementy programu znajdowały się w niewielkiej odległości od siebie.

\section{Analiza SWOT}

\section{MOCNE STRONY}

- Duży kontakt z naturą

- Oferta zapomnianej formy turystyki

- Ekologiczna konstrukcja i materiały wykończeniowe

- Usytuowanie w lesie lub nad brzegiem jeziora

\section{SZANSE}

- Przywrócenie dawnej formy turystyki

- Promowanie ekologicznego typu turystyki

- Rewitalizacja budynków z odwołaniem do lokalnego wiejskiego archetypu

\section{StABE STRONY}

- Brak zagospodarowania terenu między budynkami

- Ciemne, jednopokojowe budynki

- Brak poczucia bezpieczeństwa wśród turystów

\section{ZAGROŻENIA}

- Coraz większe zniszczenia drewna i blachy

- Utrata potencjału alternatywnej ruralistycznej turystyki na terenie Mazur

\subsubsection{KOMPLEKSOWE BUDYNKI KUBATUROWE}

Do tej grupy należą: hotel „Kormoran” w Mierkach, ośrodek wypoczynkowy „Cicha Polana” w Wałpuszu, ośrodek wypoczynkowy „Zacisze Leśne” w Medynach, ośrodek wypoczynkowy „Rudka” w Rudziskach Pasymskich oraz ośrodek wypoczynkowy „Pod Lipami” i ośrodek wypoczynkowy „Danusia” w Lidzbarku. 


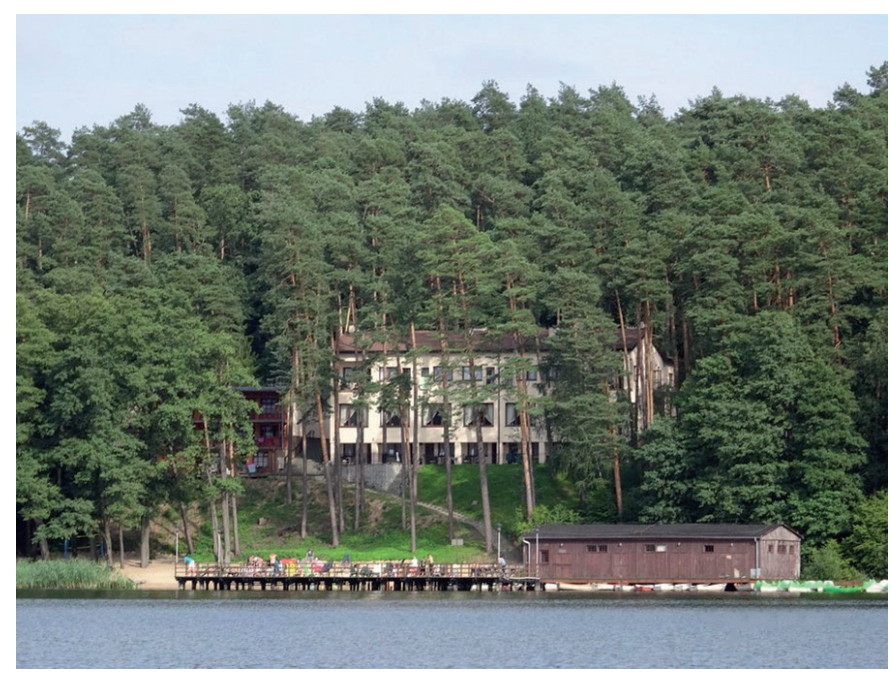

II. 5. Ośrodek wypoczynkowy „Danusia”, Lidzbark (https://www.tripadvisor.com/Hotel_Reviewg2429950-d9719439-Reviews-Danusia_Vacation_Complex-Lidzbark_Warmia_Masuria_Province_ Northern_Poland.html)

\section{Charakterystyczne cechy architektoniczne}

Obiekty wielokondygnacyjne, w większości stanowiące jedną zbitą bryłę. Niewielka integracja z terenem, wykorzystywanie takich elementów architektury jak schody i rampy. Surowe materiały budowlane. Konstrukcja z tzw. wielkiej płyty, żelbetowa, monolityczna. Brak wykończenia lub wykończenie tynkiem. Forma często nawiązująca do modernistycznych zasad kształtowania architektury: płaski dach, wsparcie na filarach, horyzontalne okna. Tworzenie wewnątrz takich samych pomieszczeń o identycznym rozkładzie, każdego z dostępem do własnego balkonu. Budynek podłużny, prostokątny, usytuowany dłuższą elewacją od strony jeziora.

\section{Materiał budowlany}

Dominuje surowy beton jako część zarówno konstrukcji, jak i wykończenia zewnętrznego. Drobne elementy architektoniczne wykonane ze stali. Często pokrycie różnokolorowym tynkiem, nadającym charakter ośrodka wczasowego. Stolarka okien i drzwi drewniana, pomalowana na biało.

\section{Funkcja i program}

Obiekt w każdym wypadku wielofunkcyjny, zapewniający wszystkie podstawowe potrzeby, jak i dodatkowy program atrakcji dla wczasowiczów. W zależności od rozmiaru inwestycji występują dawne ośrodki o funkcji wyłącznie noclegowej i restauracyjnej, jak i dodatkowo pełniące funkcję rekreacyjną. W opuszczonych ośrodkach często znajdują się dawne pomieszczenia basenu, bilard, bar i świetlica. Charakterystyczna jest również reprezentatywna 
recepcja znajdująca się tuż przy wejściu głównym. Parter przeznaczony w większości na pomieszczenia do użytku wspólnego. Piętra kształtowane w taki sam sposób na każdej kondygnacji. Wszystkie pokoje mają taki sam widok z okna.

\section{Analiza SWOT}

\section{MOCNE STRONY}

- Podobny program do obecnych nowych hoteli wypoczynkowych

- Wielofunkcyjność obiektu

- Brutalizm architektoniczny o znaczeniu historycznym

- Usytuowanie w lesie lub nad brzegiem jeziora

\section{SZANSE}

- Modernizacja i rewitalizacja

- Nowe odkrycie modernizmu i stylu vintage we wnętrzach

- Nowoczesne obiekty wypoczynkowe o światowej sławie

\section{SŁABE STRONY}

- Brak zróżnicowania w ofercie pokoi na wynajem

- Brak zagospodarowania terenu

- Przewaga jednego materiału budowlanego

\section{ZAGROŻENIA}

- Pozostawienie ogromnego nieużytecznego pustostanu

- Zanikanie turystyki w dawnych popularnych destynacjach wczasowych

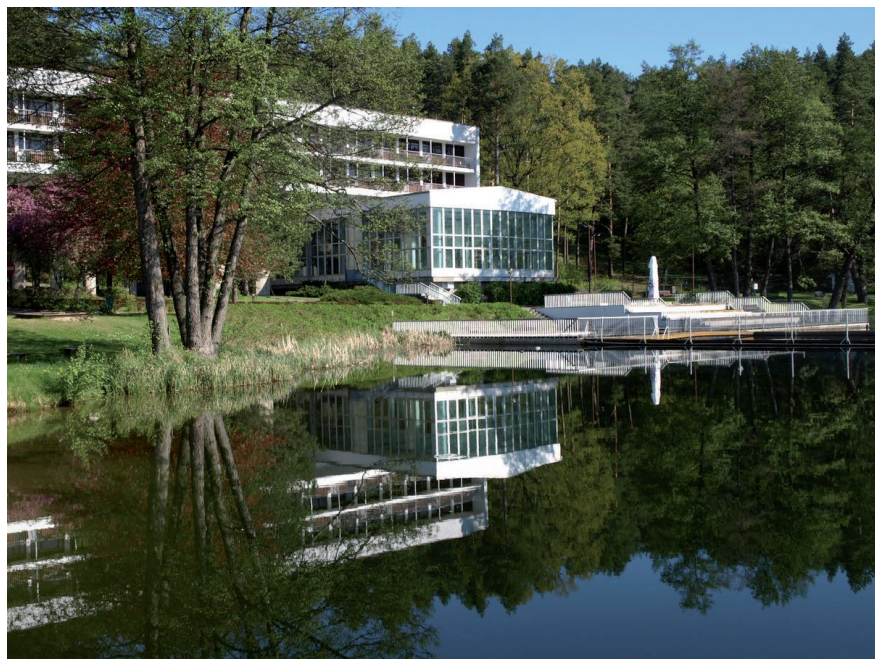

II. 6. Hotel „Kormoran”, Mierki (https://www.booking.com/hotel/pl/centrum-konferencyjnowypoczynkowe-kormoran-w-mierkach.pl.html) 


\section{WYTYCZNE DO KSZTAŁTOWANIA PROGRAMU REWITALIZACJI}

Tabela 1. Analiza porównawcza wybranych rodzajów ośrodków wypoczynkowych na terenie Mazur

\begin{tabular}{|l|c|c|c|c|c|c|c|}
\hline Typ obiektu & $\begin{array}{c}\text { Rodzaj } \\
\text { turystyki }\end{array}$ & $\begin{array}{c}\text { Struktura } \\
\text { zabudowy }\end{array}$ & $\begin{array}{c}\text { Zagospo- } \\
\text { darowa- } \\
\text { nie terenu }\end{array}$ & $\begin{array}{c}\text { Materiały } \\
\text { konstruk- } \\
\text { cyjne/ } \\
\text { wykończe- } \\
\text { niowe }\end{array}$ & $\begin{array}{c}\text { Rozkład } \\
\text { funkcji }\end{array}$ & $\begin{array}{c}\text { Integracja } \\
\text { uczestni- } \\
\text { ków }\end{array}$ & $\begin{array}{c}\text { Ekolo- } \\
\text { giczny } \\
\text { charakter } \\
\text { obiektu }\end{array}$ \\
\hline $\begin{array}{l}\text { Grupa } \\
\text { domków } \\
\text { letniskowych }\end{array}$ & Biwakowa & $\begin{array}{c}\text { Rozproszo- } \\
\text { na, wolno- } \\
\text { stojąca }\end{array}$ & Brak & $\begin{array}{c}\text { Drewno, } \\
\text { stal }\end{array}$ & $\begin{array}{c}\text { Częściowo } \\
\text { skupiony }\end{array}$ & Niewielka & Tak \\
\hline $\begin{array}{l}\text { Niska } \\
\text { zabudowa } \\
\text { szeregowa }\end{array}$ & $\begin{array}{c}\text { Kolonijna, } \\
\text { związków } \\
\text { zawodo- } \\
\text { wych }\end{array}$ & $\begin{array}{c}\text { Rozproszo- } \\
\text { na, szere- } \\
\text { gowa }\end{array}$ & Niewielkie & $\begin{array}{c}\text { Beton, } \\
\text { cegła, } \\
\text { drewno, } \\
\text { stal }\end{array}$ & Rozpro- \\
szony & Duża & Nie \\
\hline $\begin{array}{l}\text { Wolnostojące } \\
\text { obiekty } \\
\text { kubaturowe }\end{array}$ & $\begin{array}{c}\text { Uzdrowi- } \\
\text { skowa, } \\
\text { wypoczyn- } \\
\text { kowa }\end{array}$ & $\begin{array}{c}\text { Skupiona, } \\
\text { wolnosto- } \\
\text { jąca }\end{array}$ & $\begin{array}{c}\text { Brak lub } \\
\text { niewielkie }\end{array}$ & $\begin{array}{c}\text { Beton } \\
\text { zbrojony, } \\
\text { stal }\end{array}$ & Skupiony & Średnia & Nie \\
\hline
\end{tabular}

Źródło: opracowanie własne

Opuszczone lub upadające dawne ośrodki wczasowe, budowane w latach 1945-1989, mają duży potencjał i ponownie mogą stać się atrakcyjnymi miejscami turystycznymi. Konieczna jest sprecyzowana rewitalizacja, odmienna dla każdego typu zabudowy. Analiza SWOT wykazała zalety dawnych ośrodków, przy czym głównym ich atutem jest miejsce położenia, zazwyczaj oddalone od centrum miast. Przedstawione aspekty formy architektonicznej, użytych materiałów i rozkładu funkcji pozwalają wyłonić elementy, które są kluczowe, aby przyciągnąć turystów w zapomniane lokalizacje.

Ośrodki letniskowe funkcjonujące jako skupiska osobnych domków stanowią odpowiedź na potrzebę izolacji od struktury miejskiej i biwakowego rodzaju turystyki. Są również ekologicznym rozwiązaniem dla osób nieszukających wygód, a raczej kontaktu z naturą. Największym minusem takiego rozwiązania jest mała integracja między obiektami, wynikająca z braku zagospodarowania terenu, przez co wydają się one nienadzorowane, przypadkowe i niebezpieczne.

Ośrodki niskie w zabudowie szeregowej są rozwiązaniem integrującym społeczność turystów. Oferują zarówno prywatność w osobnej części noclegowej, jak i komunikację w strefach wspólnych. Największe minusy to brak zróżnicowania oferty noclegowej i niewielkie rozmiary domków. Problemem są też wspólna łazienka i toaleta, które nie spełniają obecnych standardów i potrzeb. Brakuje tu ponadto odpowiednich pomieszczeń socjalnych, takich jak bawialnia dla dzieci, pomieszczenia do pracy zdalnej, biblioteka, restauracja, siłownia, centrum odnowy biologicznej, które mogą zastąpić dawną stołówkę, świetlicę i wspólną łazienkę. 
Wielofunkcyjne obiekty budowane z wielkiej płyty są ośrodkami programowo nieodbiegającymi od obiektów obecnie budowanych na terenie Mazur. Ich przewagą jest usytuowanie w mniej eksplorowanych destynacjach, niezniszczonych przez nadmierną turystykę. Wykazują potencjał, aby stać się ciekawą odmianą turystyki z zachowaniem swojego unikatowego charakteru dawnych lat. Wymagają jednak dostosowania pod względem projektowania uniwersalnego, a także większego zagospodarowania terenu dookoła.

Mazury jako obszar w dużej mierze ukierunkowany na turystykę posiadają znaczny zasób niewykorzystanych obiektów wypoczynkowych w miejscowościach, które niegdyś były znaczącymi ośrodkami turystycznymi. Zgodnie z zasadą zrównoważonego projektowania należałoby sklasyfikować konkretne grupy obiektów i stworzyć program rewitalizacji, który przyciągnąłby nowych turystów. Obiekty budowane w latach 1945-1989 odpowiadały nagłej potrzebie turystyki krajowej, która z czasem, ze względu na ekspansję zagraniczną, zanikła. Wykorzystanie obecnych pustostanów to szansa na odmienną i ciekawszą turystykę, która jest w stanie przywrócić świetność zapomnianym obszarom Mazur.

Analiza wybranych obiektów pozwala sprecyzować kilka koniecznych działań, które mogą przywrócić funkcjonalność opuszczonym obiektom turystycznym. Pierwszym aspektem jest konieczność dostosowania funkcji do potrzeb nowego konsumenta, z zapewnieniem odpowiedniej równowagi między prywatnością a integracją. Kolejnym koniecznym punktem programu rewitalizacji jest zagospodarowanie terenu dookoła obiektów, dzięki czemu podwyższy się ich standard bezpieczeństwa, a także możliwe będzie korzystanie z ośrodków przez osoby niepełnosprawne. Następnie warto zwrócić uwagę na:

- komunikację i dostosowanie obiektów pod względem potrzebnych parkingów;

- użycie materiałów, głównie wykończeniowych (zastosowanie ciepłych i naturalnych materiałów nada obiektom charakter bardziej wiejski niż miejski);

- dostosowanie charakteru danego budynku do lokalnego archetypu i tradycji miejsca;

- nadanie konkretnym miejscom wyjątkowości za pomocą odmiennej oferty turystycznej;

- zadbanie o aspekt ekologiczny (modernizacja budynków pod względem infrastruktury technicznej i odnawialnych źródeł energii).

\section{PODSUMOWANIE}

Mazury dysponują unikatowymi na skalę światową walorami przyrodniczymi. Są ciekawym i nieodkrytym miejscem nie tylko dla turystów z zagranicy, ale również z kraju. Obecnie podróżowanie w te rejony ogranicza się do kilku najpopularniejszych miejsc, tymczasem dawne świetne tereny ośrodków wczasowych popadły w zapomnienie. Kluczowym momentem w historii turystyki na tych obszarach był okres powojenny, kiedy w tym miejscu zaczęły powstawać nowe, zróżnicowane oferty noclegowe. Dawne ośrodki zmieniły się jednak w opuszczone ruiny lub chylą się ku upadkowi. Mają jednakże ogromny i niewykorzystany 
potencjał rewitalizacji i przywrócenia dawnej świetności w odświeżonej formie. Ważne, aby postawić sobie pytanie, czego oczekuje nowy, współczesny konsument i co z tego jest w stanie zaoferować dawna architektura z czasów Polski Ludowej, a co powinno zostać zmienione i dostosowane na nowo. W imię zasady zrównoważonego rozwoju nie można myśleć o rozwoju turystyki przez tworzenie nowych miejsc, skazując dawne na zapomnienie. Rola rewitalizacji jest tu kluczowym elementem, dzięki któremu w przyszłości Mazury nie staną się szlakiem ruin dawnych stylów architektury turystycznej.

\section{BIBLIOGRAFIA}

Achremczyk, S. (2010-2011). Historia Warmii i Mazur. T. 1-2. Olsztyn: Towarzystwo Naukowe oraz Ośrodek Badań Naukowych im. Wojciecha Kętrzyńskiego w Olsztynie.

Cymer, A. (2018). Architektura w Polsce 1945-1989. Warszawa: Centrum Architektury.

Cymer, A. (2016). Luksusowe domy wczasowe doby PRL-u. Niektóre wciqż istniejq!. Pobrane z: https://www.bryla.pl/bryla/56,85301,11584379,Wakacje_w_stylu_PRL.html (dostęp: 29.04.2020).

Gryszel, P. (2021). Zarys historii turystyki w Polsce. Pobrane z: https://www.lotur.eu/ UploadFiles/524/178/1265187566-Historia_turystyki_w_Polsce_DOT_IT.pdf (dostęp: 24.04.2021).

Jastrzębska, A. (2017). Wczasy w PRL-u i dziś - jak Polacy odpoczywali przed laty i jak robiq to dziś. Pobrane z: https://turystyka.wp.pl/wczasy-w-prl-u-i-dzis-jak-polacy-odpoczywali-przed-laty-i-jak-robia-to-dzis-6123320377497217a (dostęp: 29.04.2020).

Kamińska, A. (2020). Wakacje w czasach PRL. Kaowiec, konserwy w plecakach i Słoneczny Brzeg. Zdjęcia. Pobrane z: https://dziennikbaltycki.pl/wakacje-w-czasach-prl-kaowiec-konserwy-w-plecakach-i-sloneczny-brzeg-zdjecia/ar/c15-15083905 (dostęp: 12.04.2020). mz. (2017). Kuracjusze i wczasy zakładowe. Najbardziej znane ośrodki wczasowe z PRL-u. Pobrane z: https://www.bryla.pl/bryla/56,85301,20241982,kuracjusze-i-wczasy-zakladowe-najbardziej-znane-osrodki.html (dostęp: 18.03.2020).

Naruszewicz-Duchlińska, A. (2004). Nazewnictwo na Warmii i Mazurach. Pobrane z: https://www.academia.edu/1896365/Nazewnictwo_na_Warmii_i_Mazurach (dostęp: 24.04.2021).

Sakson, A. (1990). Mazurzy - społeczność pogranicza. Poznań: Instytut Zachodni.

Urząd Marszałkowski Województwa Warmińsko-Mazurskiego. (2016a). Analiza sytuacji społeczno-gospodarczej województwa warmińsko-mazurskiego na rok 2015. Olsztyn.

Urząd Marszałkowski Województwa Warmińsko-Mazurskiego. (2016b). Strategia Rozwoju Turystyki Województwa Warmińsko-Mazurskiego do roku 2025. Olsztyn.

Urząd Statystyczny. (2020). Raport o sytuacji społeczno-gospodarczej województwa warmińsko-mazurskiego 2020. Olsztyn. 
Urząd Statystyczny. (2020). Województwo warmińsko-mazurskie w liczbach 2020. Olsztyn. Wasyluk, P., Kucner, A., Sierocki, R., Kuczyński, B., Romancewicz, K., Wieczorek, A., Żurowska, J. (2018). Raport. Turystyka Warmii i Mazur. Pobrane z: http://www.uwm.edu.pl/trendy/ gfx/AIKT_TURYSTYKA_WiM_RAPORT.pdf (dostęp: 25.04.2021).

http://www.kalwa-energopol.pl/ (dostęp: 04.05.2020)

https://www.zaplanujwczasy.pl/noclegi+ruciane-nida/bielanka,41562.html (dostęp: 04.05.2020)

https://zapytajonocleg.pl/obiekt-27245-olsztynek-relaks-osrodek-wypoczynkowy-swierkocin (dostęp: 04.05.2020)

https://e-turysta.pl/osrodek-wypoczynkowy-mazury-krzyze-100661.html?kl=1 (dostęp: 10.06.2021)

https://www.booking.com/hotel/pl/centrum-konferencyjno-wypoczynkowe-kormoran-w-mierkach.pl.html (dostęp: 04.05.2020)

https://www.tripadvisor.com/Hotel_Review-g2429950-d9719439-Reviews-Danusia_Vacation_Complex-Lidzbark_Warmia_Masuria_Province_Northern_Poland.html (dostęp: 04.05.2020) 
